\title{
TTR
}

Traduction, terminologie, re?daction

\section{Clem Robyns, ed. Translation and the (Re)production of Culture. Selected Papers of the CERA Research Seminars in Translation Studies 1989-1991. Leuven, CERA Chair for Translation, Communication and Cultures, 1994, 321 p.}

\section{Judith Woodsworth}

Volume 7, numéro 2, 2e semestre 1994

Traduire les sociolectes

URI : https://id.erudit.org/iderudit/037188ar

DOI : https://doi.org/10.7202/037188ar

Aller au sommaire du numéro

Éditeur(s)

Association canadienne de traductologie

ISSN

0835-8443 (imprimé)

1708-2188 (numérique)

Découvrir la revue

Citer ce compte rendu

Woodsworth, J. (1994). Compte rendu de [Clem Robyns, ed. Translation and the (Re)production of Culture. Selected Papers of the CERA Research Seminars in Translation Studies 1989-1991. Leuven, CERA Chair for Translation,

Communication and Cultures, 1994, 321 p.] TTR, 7(2), 219-224.

https://doi.org/10.7202/037188ar d'utilisation que vous pouvez consulter en ligne.

https://apropos.erudit.org/fr/usagers/politique-dutilisation/ 
Clem Robyns, ed. Translation and the (Re)production of Culture. Selected Papers of the CERA Research Seminars in Translation Studies 1989-1991. Leuven, CERA Chair for Translation, Communication and Cultures, 1994, 321 p.

For the past six years, the University of Leuven's CERA Chair has been giving young scholars an opportunity to rub shoulders with experienced 
and distinguished scholars. The Chair attracts participants from near and far: Australia, Belgium, Finland, Germany, Hong Kong, Turkey and the US, to name but a few of the countries of origin. It pursues the line of work initiated by the Leuven group, also referred to as the "Manipulation School ${ }^{1} . "$

Editor Clem ROBYNS introduces the collection in a preface entitled "Translation Studies: The Next Generation," in which he skilfully weaves together the various themes which emerged over three successive summers of CERA Research Seminars. In many respects, this preface - very much like Susan BASSNETT's "Afterword" — reads like a manifesto, more like a celebration of achievements than a neutral presentation of a collectively produced volume. But he has cause to be proud: no longer preoccupied with fighting the "battles" of the previous generation, ROBYNS and his contemporaries have rigorously explored the diverse facets of translation, viewed "not as a secondary text, but an event, an interpretation, a discursive practice" (p. 3).

The book is divided into three sections, one for each of the three sessions covered: the 1989 session at which Gideon Toury was the CERA Chair Professor, the 1990 session under Hans J. Vermeer, and the 1991 session under Susan Bassnett. This is a division which reflects a student/teacher relationship: one of fledgling scholars still paying tribute to their masters. It might have been possible, indeed more useful, to divide the collection up according to theme, focus, or approach.

Several of the authors examine translation from the perspective of a particular historical and cultural context. In Annick CAPELLE's study of nineteenth-century Belgium, translation is set against the background of the 1830 revolution, a reaction to the establishment of Dutch as the official language. Reine MEYLAERTS, too, discusses the search for a national literature in the 160 years of Belgian history and

1. After Theo Hermans, ed. The Manipulation of Literature. Studies in Literary Translation (London, Croom Helm, 1985). Among the seminal papers contained in the collection, the article entitled "On Describing Translations," by J. Lambert and H. Van Gorp, stands out as a theoretical model which seems to have guided several of the contributors to the present volume. 
focuses, in particular, on translational policy and practice in Belgium between the two World Wars.

Mary STEELE takes a look at translation in a quite different context - that of the former Soviet Union, where copyright legislation and other factors led to massive translation of literature from Russian into English within the source-language culture, rather than outside it, with inevitable "macrostructure alterations." Gabriele PISARZ contributes a fascinating and original study of the translational reception of American socialist writers in East and West Germany during the postwar period, showing the extent to which the different treatment of the same writers reflects "the two different norm systems prevailing in Germany" (p. 269).

Several of the contributions deal with specific authors or works, examined from the perspective of translation and reception. Using the theoretical framework developed by the Göttingen group, Isa HÖFLICH studies the fortune of the Brontë sisters in Germany, concentrating in particular on the "genealogy" of translations of Wuthering Heights (p. 195). Julian A. ROSS compares an English translation (The Sorrow of Belgium) with its Belgian source text (Het Verdriet van België). Using the Lambert and Van Gorp model, he shows how a translation functions as a "text in its own right in the target cultural/literary system" (p. 83). This is one of the underlying assumptions of the Leuven group, actually, and it is no surprise, therefore, that it appears in so many of the papers. In this instance, the method reveals translation strategies that serve to remove some of the "foreignness" of the book, such as deliberately omitting or clarifying passages deemed to be "too obscure or confusing for English-speaking readers" (p. 87). Julien VERMEULEN shows how two different Dutch translators have handled the work of Négritude poet Léopold Sédar Senghor. While written in the French language, the source text does not belong exclusively to the French literary system, for African values and the Négritude ideology are "reflected and refracted in French" (p. 113). Using the concept of the "prototext," Vermeulen identifies interferences in the source text which "refer to the underlying African literary system, language and culture" (p. 113) and which must be taken into account during the translation process. 
Some of the papers concentrate on certain literary genres. Children's literature is the subject of two articles. Karin VAN CAMP surveys the translation of the popular Pippi Longstocking, a children's work originally written in Swedish, and studies the relation of the Dutch translation to an intermediate German one. Using two Finnish translations of The Wizard of $O z$, Tiina PUURTINEN tests the theoretical approaches of a number of scholars (Toury, Reiss, House, and others) with a view to discovering new parameters for determining the "acceptability" of translations of children's literature. Drama translated in Spain from the 1950s to the 1980s is discussed in an article by Raquel MERINO, once again on the basis of the Lambert/Van Gorp framework. Poetry is the subject of Andrew SHIELDS's piquant effort to refute Robert Frost's negative epigram, "Poetry is what gets lost in translation." He presents Walter Benjamin's allegoric and metonymic translations of Baudelaire's Tableaux parisiens cycle, offering us a view of translated poetry as a "doubled reading" or, to use his own neologism, as "Nebensetzen" ("setting next to," in opposition to Übersetzen, "setting over"). Thus, poetry is "what gets found in translation" (p. 315).

Various aspects of translated literature are treated in papers such as Marta MATEO's "The Translation of Irony" and Nelleke de JONG-van den BERG, "Narrator and Time - Translator and Time". Non-literary forms are not totally neglected, however. Marja JÄNIS and Timo PRIKKI conduct research on tourist brochures produced in Finland for the benefit of visitors from the (former) Soviet Union. These brochures have been translated into Russian in accordance with the norms of the source rather than the target culture, but have nevertheless been found satisfactory by the tourists using them. While contrary to the initial assumptions of the authors, the findings did support one of their hypotheses, namely the "tolerance of strangeness among tourists as receptors of tourist information" (p. 53). This conclusion is rich in possibilities for other forms of translation as well. Delving into an entirely different realm, Anneke de VRIES provides a detailed history of a twentieth-century Dutch Roman Catholic translation of the Bible.

Some of the papers, as Robyns says, seem to question each other and can be read as "a critical comment on all the others" (p. 2). 
This is true for "The Concept of Interpretation in Descriptive Translation Studies: First Explorations" by Cees KOSTER and "The Task of the Describer: Between Two Meanings of 'Interpreter'" by Matthijs BAKKER. Koster proposes to examine the "metatheoretical aspects of translation description" in the form of a "dialogue" with Gideon Toury's theories, while Bakker underlines the "interpretative moves of the describer" (p. 169) as a reader of source and target texts.

One of the more substantial, and more abstract, pieces is Clem ROBYNS's "Translation and Discursive Identity" (also published in Poetics Today, XV-1). The paper defines four attitudes toward what he calls "discursive migration": the imperialist, defensive, transdiscursive and defective stands, each illustrated by pertinent examples drawn from a range of discourse types (literary, academic, cinematographic, etc). Robyns concludes by applying his method to translation studies itself, in which the lack of a distinct identity has led to a "defective attitude toward other disciplines;" what he proposes instead is a "transdiscursive doctrine" whereby translation studies would study the ways in which it relates to other discourses.

As in many international enterprises, English has been chosen as the language of exchange. Inevitably, this has had an impact on the quality of language and readability, despite the best efforts of the editorial team.

As Robyns points out in his introduction, the papers contained in the volume are "reports on research in progress." Questions are raised, and some left unanswered. Many of the authors present their work tentatively, as does Robyns: "only a first attempt to develop the theoretical framework of a larger research project" (p. 57). Some readers may well tire of the succession of questions left up in the air, as well as the relentless reiteration of the theoretical constructs of translation studies. However, this volume can also be regarded as a collection of hors-d'auvre, a refreshing foretaste of stimulating booklength studies yet to come.

In fact, these "rising stars of translation studies" as Susan Bassnett calls them (p. 319), illustrate the very meaning of the word "school" as applied to the Leuven group: not merely a theoretical and 
methodological stance, it has also served as a nursery, a breedingground, a true centre of training for future scholars. For this, credit must be given to the team of regular supervisors (Lieven D'hulst, Theo Hermans and others), to the various CERA Chair Professors (who in addition to the ones named above have included Mary Snell-Hornby, Daniel Gile and Albrecht Neubert in recent years), and most especially to director José Lambert, who in the words of Clem Robyns: "never stops having six revolutionary ideas a day, and never gets tired of stimulating young people to become enthusiastic scholars" (p. 5).

Judith Woodsworth Concordia University 